\title{
DISKUSSIE
}

\section{GELOOF EN DIE WOORDEBOEK VAN DIE VERBONDSVERKEER}

In antwoord op die (deur my gewaardeerde) kritiek van dr. C. van der Waal' ${ }^{\text {) }}$ op my gebruik van die woord "geloof" gee ek eers 'n eie saamvatting daarvan, toegepas op ons Calvinistiese wysbegeerte.

\section{Samevatting.}

„Die Calvinistiese wysbegeerte kan net daarby wen as dit (veral in ons eeu van verfynde humanisme) die taal van Gods Woord en van ons belydenis handhaaf. Die Calvinistiese wysgeer behoort hom van 'n eie (aan die Heilige Skrif en aan ons Gereformeerde belydenis ontleende) terminologie te bedien. Dit betref besonderlik die woord ,geloof". Met sy bedie. ning van die woordeboek van die ver. hondsverkeer met God, onse Vader in Jesus Christus, behoort hy aan die woord "geloof" uitsluitlik die betekenis te heg wat dit in Skrif en belydenis het. nl. "geloof in die evangelie van Jesus Christus". Hy mag nie daaraan ook betekenisse heg, wat die ongelowige ook daaraan kan gee nie. Die ongelowige verwerp die evangelie-geloof. Hy glo nie. Ongeloof is geen geloof nie. Dit is 'n ongehoorsame verwerping daarvan. Tussen geloof en ongeloof bestaan 'n radikale antitese, 'n antitese wat die Calvinistiese wysgeer ook terminologies tot sy reg moet laat kom. Ongeloof mag nooit geloof genoem word nie. Veral ook met ons Calvinisties wysgerige denke hehoort ons die woord „geloof" uitsluitlik te reserveer vir „evangeliegeloof"; geen ander betekenis mag aan die woord "geloof" geheg word nie.

Stoker daarenteen onderskei tussen 'n geloof in ruimer sin' en 'n ,geloof in enger sin' en m.b.t. laasgenoemde tussen 'n ,godsdienstige geloof' en 'n ,religieuse geloof - onderskeidings wat die Heilige Skrif nie ken nie. So gee hy aan die woord ,geloof' ook nog 'n ander inhoud as wat Gods Woord en ons belydenis doen. Hy wek daardeur misverstand. Hy bemoeilik daardeur die verstaan van die Skrif (i.c. die verstaan van wat die Skrif met geloof' bedoel). $\mathrm{Hy}$ ondermyn daardeur ons skriftuurlike belydenis. Deurdat hy onder 'geloof' nie uitsluitlik ,evangeliegeloof' verstaan nie, en van 'n ,algemene geloof' uitgaan waarvan ,evangeliegeloof' 'n verbesondering is, kan hy in sy woordgebruik die radikale antitese tussen geloof en ongeloof nie tot sy reg laat kom nie. Deur sy afvlakking van die betekenis van die woord geloof gaan hy teen Skrif en belydenis in en gee hy ' $n$ toegangspoort aan die humanisme. Hy doen dit, terwyl hy as Calvinistiese wysgeer aan die terminologie van sy bellydenis gebind is. Hiermee bewys hy aan ons Calvinistiese wysbegeerte 'n ondiens."

Hierdie samevatting stel die kritiek van my kritikus nie so takties as hy nie en skerper as hy, om sodoende sy besware 
so duidelik en skerp moontlik te stel. Ek vind dit net jammer dat hy, voordat hy sy kritiek geskryf het, nie my (so pas verskene) Beginsels en Metodes in die Wetenskap gelees het nie. Want daarin verval ek (juis ook wat die woord ,geloof" betref) in nog meer (indien nie erger) terminologiese "ketterye" (in goed bedoelde $\sin$ verstaan). Dit gaan hier egter (soos dr. v. d. W. tereg meen) om veel meer as net 'n terminologiese geding. Want in die stryd om die waarheid (wat in elkeen se hart en teen ander gestry word, en wat ook op wysgerige gebied 'n faset is van die stryd tussen die Ryk van die Lig en die ryk van die duisternis) het ook die woordgebruik 'n beslissende betekenis, juis omdat woorde betekenisse het $^{2}$ ).

\section{Instemming en verweer.}

Met wat my geagte kritikus oor ,evangeliegeloof" sê, gaan ek akkoord ${ }^{3}$ ). Tereg onderstreep hy dat in ons Calvinistiese wysbegeerte die radikale antitese tussen Christelike geloof en ongeloof ook terminologies tot sy reg moet kom. Die vraag is egter: hoe? Sy eis van 'n woordebock van die verbondsverkeer is pakkend en geregverdig. Want ook wysgerige terminologie is nie ,religieus-neutraal" nie. So sal in ons wysgerige woordeboek bv. nie staan: "mens: 'n redelike-sedelike dier" nie. Maar daarin mag ook woorde voorkom wat andersdenkendes in dieselfde betekenis as ons gebruik, bv.: ,getal: diskrete kwantiteit". Woorde word immers óók gevorm na aanleiding van wat gelowiges en ongelowiges gemeenskaplik (as mense van gelyke maaksel in dieselfde wêreld) ervaar. Bowendien is daar in ons bedeling ook ' $n$ verkeer en selfs 'n arbeidsgemeenskap (op allerlei terrein) van gelowiges en ongelowiges vir sover aan die mensheid 'n gemeenskaplike taak gegee is. Maar ons geloof verplig ons om ook in hierdie arbeidsgemeenskap om die waarheid te worstel en i.c. om ook in ons woordgebruik Calvinistiese Wysbegeerte (Wysbegeerte ,in U lig") te beoefen.

'n Woordeboek van die verbondsverkeer is egter onvoldoende.

Want 'n taal (ook ons wysgerige taal) bestaan nie net uit woorde met hul betekenisse (resp. hegrippe) nie, maar ook uit sinne met hul betekenisse (resp. gedagtes, oordele). Taal het immers twee wortels: a. benoeming (waarin die woord sy oorsprong vind) en b. spreke (waarvan die sin - met sy artikulasie - die eenvoudigere, vorm' is). Die een is nie tot die ander herleibaar nie, en albei is essensieel op mekaar aangewys. Ook met ons vorming van sinne met hulle betekenisse (resp. gedagtes, oordele) moet ons $\mathrm{Cal}$ vinistiese wyshegeerte beoefen. Dit hou in dat, al sou ek die woord ,geloof" óók in betekenisse gebruik waarin andersdenkendes dit gebruik, my taal nogtans Calvinisties kan wees, die antitese-styl kan vertoon en in verbondsverkeer kan staan.

\section{Woordgebruik.}

Dr. v. d. W. verlang dat ek die woord "geloof" net in die één betekenis van ,evangeliegeloof" sal gebruik. Daargelate dat Gods Woord (al is dit uitsonderlik) die woord "geloof" (Pistis) ook in ander betekenisse gebruik (vgl. bv. 1 Kor. 2 : 5$)^{4}$ ), en dat my kritikus sélf die woord ,geloof"' in 'n ook ander betekenis gebruik ${ }^{5}$ ), sal hy my 'n diens bewys, 
as hy vir daardie ander betekenisse waarin ek die woord "geloof" ook gebruik, ánder woorde aan die hand sou gee, wat my bedoeling nét so skérp uitdruk. Omdat hy dit m.i. nie sal kan doen nie, blyk hieruit dat ons hier met ingewikkelder probleme te doen het as wat hy stel.

Sou mens dr. v. d. W. se eis mag generaliseer, nl. dat aan 'n woord (i.c. ,geloof') net één betekenis geheg kan word? (Die volgende voorbeelde is opsetlik beperk tot woorde wat ook in die Skrif voorkom). As die woord "God" nét ,die lewende ware God Drie-enig" mag beteken; as ons onder die woord "genade" nét "Gods genade" mag verstaan; as ons aan die woord "openbaring" nét die betekenis van "Gods openbaring" mag heg; as die woord "waarheid" nét "God Drie-enig as Waarheid" mag bete. ken; as ons onder die woord "skepping" nét „Gods skepping" mag verstaan; en as ons onder die woord "godsdiens" nèt die betekenis van ,die ware Christelike godsdiens" mag heg; - dan sou respektiewelik Gods Woord mense nie "gode" mag noem en sou ons nie van ,heidense gode" (was as heidense gode afgode is) mag spreek nie, en sou ons ook nie mag spreek van 'n ,genadige" vonnis van 'n regter, van 'n mens wat sy innerlike gevoelens "openhaar", van „ware" kennis en ,ware" kuns, van menslike ,skepping" en van Joodse, Mohammedaanse en Indiese ,godsdienste" nie. Sou 'n dergelike generalisasie nie teen die aard en ontwikkeling van die taal en van sy norme (as táál-norme) ingaan, die taal in 'n gemeganiseerde keurslyf dwing wat met sy wese in stryd is, sy ontwikkeling strem, sy soepele seggingskrag fnuik en dit bo- wendien onhanteerbaar $\left.{ }^{6}\right)$ maak nie? Sou dieselfde nie tot 'n hoë mate kon geld vir die eis dat die woord "geloof" nét ,evangeliegeloof" mag beteken nie?

'n Goeie grond waarom woorde (ook die woord "geloof") meer as een betekenis verkry, is dat die verskeidenheid wat ons benoem, ook samehange, verbande, ooreenkomste, verhoudings, analogieë, ens. bied. Ander gronde is implisiet in die vorige paragraaf gegee. Tereg sal dr. v. d. W. hierteen as verweer kan stel dat ons ten minste wetenskaplike (w.o. wysgerige) woorde sal presiseer. Dit hou egter nie in dat in álle gevalle één woord net één betekenis sal hê nie. Presisering van betekenisse kan bv. met behulp van byvoeglike naamwoorde geskied; so spreek my kritikus sélf van bv. "ongehoorsame" verwerping, „skriftuurlike” belydenis, „algemene" genade, „besondere" genade, "menslike" eienskap, „ware" kerk, "valse" kerk, „ekumeniese” instelling, „ekumeniese" beweging, „ware" (sic!) geloof, ens. en ek van bv. "geloof in enger sin" en "geloof in ruimer sin". Presisering van betekenisse kan ook deur woordkoppeling geskicd, bv.: „evangelie-geloof”; of deur bv. die sinsverhand waarin ' $n$ woord voorkom: so sal niemand bv. "geloof aan die bewyskrag van die rede" verwar met „evangeliegeloof" nic. So is daar nog ander wyses van presisering van woordbetekenisse. Van my presisering van die onderskeie betekenisse van die woord "geloof" hoef dan ook nie te geld dat dit misverstand verwek, die belydenis ondermyn, nie die antitese tussen Christelike geloof en ongeloof tot sy reg laat kom, in stryd met die woordeboek van die ver. bondsverkeer is, ens. nie. 
'n "Algemene"(?) geloof.

Tot dusver het ek die kernbeswaar van my kritikus nog nie ontsenu nie. Die angel van sy kritiek (wat ek moet verwyder) gee hy reeds met die opskrif van sy bydrae in Koers: ,'n Algemene geloof?"

Dr. v. d. W. gaan van die foutiewe veronderstelling uit dat ek ,geloof in enger sin" (w.o. "godsdienstige geloof" en "religieuse geloof") en "geloof in ruimer sin" volgens die skema "algemeenbesonder" aaneenskakel, waarvolgens 'n ,algemene geloof" bestaan, waarvan „evangeliegeloof”, Spinoza se „panteïstiese geloof" aan sy substansie- of natuurgod, die „Indiese geloof”, die ,geloof aan feite", die "geloof aan die bewyskrag van die rede", ens. verbesonderings (resp. besondere eksemplare) sou wees. Was sy veronderstelling juis, dan was ál sy kritiek (aan die end van my Samevatting opgesom) ter sake.

Dat daar woorde met hul betekenisse (asook begrippe) is, wat volgens die skema "algemeen-besonder" gevorm word, is bekend genoeg. Maar woord- (asook begrips-) vorming geskied nie net volgens hierdie skema nie. Wyses waarvolgens verskillende betekenisse van dieselfde woorde onderling geskakel is, is byna net so gevarieerd soos die verskille van verbande, samehange, ooreenkomste, verhoudings, analogieë, ens. wat die gegewe verskeidenheid bied $^{7}$ ). Dit geld natuurlik van wetenskaplike terminologie in mindere mate en veelsins op ander wyse as van die „gewone" tale. Hierop gaan ek nie in nie, maar merk net op dat juis ook wetenskaplike terminologie nie net volgens die denkskema „algemeen-besonder” gevorm word nie, soos dit m.b.t. die woord ,geloof" vervolgens blyk.

Geloof in enger $\sin ^{7 a}$ ).

Daar is nie so iets soos 'n ,algemene geloof" nie. Die onderskeie betekenisse wat ek aan die woord "geloof" heg is geen verbesonderings van 'n ,algemene geloof" (wat nie bestaan) nie. Hulle skakel op ' $n$ ander wyse as volgens die skema "algemeen-besonder".

Volgens my kritikus het nie alle mense "geloof" nie, maar slegs hulle wat in die evangelie van Jesus Christus glo. Die ongelowige mense (wat volgens hom geen "geloof" het nie) is natuurlik nog ménse. Die gelowiges kry dus iets (nl. "geloof") by, wat die ongelowiges as ménse nje het nic. Hierdie beskouing kom gevaarlik naby dic Rooms-Katolieke opvatting van ,geloof" as 'n ,superadditum", as iets waarsonder die mens nog mens kan wees, maar wat die gelowige as iets ekstras van God by-geskenk kry.

Meer skriftuurlik (en beter passend in ons woordeboek van die verbondsverkeer) is m.i. die heskouing van Calvyn. Die mens is geskape om God te ken, lief te hê en te dien. Hierdie "geloofsaanleg" (daargelate of mens dit saam met Calvyn 'n ,semen religionis" en 'n ,sensus divinitatis" of iets anders moet noem) het elke mens as mens. Daarsonder kan hy nie mens wees nie. 'n Superadditum is dic „geloofsaanleg" dus nie. Sonder hierdie (ingeskape resp. aangebore) "geloofsaanleg" sou die in sonde gevalle mens nic God kon verwerp en in 'n afgod kon glo nie. Die „geloofsaanleg" is geen ,algemene geloof" nie, maar bied nog slegs die geskenkte moontlikheid on te glo. Dit 
moet dan ook van die "geloof" (die aktuele geloof, die geloofshandeling of geloofsakte ${ }^{7 b}$ ), die geloof aan God of 'n afgod) onderskei word. Ook „ongeloof” is aktueel en veronderstel die ,geloofsaanleg"; dit is nie net 'n verwerping van God nie, maar is in 'n onware (afvallige) geloof aan 'n vermeende „hoër" wese gegrond.

Alle mense glo; hulle glo óf aan die ware God of aan een of ander afgod $\left.{ }^{8}\right)$. Die disjunksie "of ... of " is hier van funda. mentele belang. Dit is bedenklik om te sê: "alle mense glo aan 'n hoëre wese". Want mens sou die "hoëre wese" volgens die skema „algemeen-besonder" as 'n algemene bepaling kon opvat, waarvan die "ware God" en die onderskeie "afgode" verbesonderings (besondere eksemplare) sou wees; en dit sou impliseer dat daar 'n "algemene geloof" sou wees waarvan die „ware geloof" (resp. „evangeliegeloof”) en „onware of valse geloof" (resp. „ongeloof") verhesonderings sou wees. Daarmee sou die skriftuurlike radikale antitese van die ware God en die onderskeide „afgode”, asook van ,ware geloof” en ,onware geloof" gerelativeer word. Net so $\min$ as wat daar 'n "hoër wese" bestaan waarvan die "ware God" en die onderskeie „afgode" verbesonderings is, net so min bestaan daar 'n ,algemene geloof", waarvan „ware geloof" en „onware geloof" verbesonderings is ${ }^{9}$ ). Handhaaf ons egter die hierbo genocmde disjunksie, dan bly die skriftuurlike antitese gewaarborg, en is van die betrokke verbesonderings geen sprake meer nie.

Tereg beweer dr. v. d. W. dat geloof geen leë dop is wat gevul moet word nie. Dit waaraan jy glo en jou geloof daaraan kan mens nie skei nie. Maar dit geld sowel van die „ware geloof” ( resp. „evangeliegeloof") as van die „onware geloof". Juis daarom is hulle so verskillend en geen verbesonderings van 'n ,algemene geloof" nie.

Tog mag ek ware en onware geloof albei ,geloof" noem, omdat albei die ,geloofsaanleg" veronderstel, omdat die aktuele geloof by albei („subjektief”) gekenmerk word deur 'n sekere kenne, vaste vertroue en onvoorwaardelike oorgawe aan ' $n$ hoëre wese (aan God of aan een of ander afgod) en omdat by albei die geloof (hoe ook al op verskillende wyse) die ganse lewe van die "gelowende" omspan, stempel en beheers. Omdat ,geloof" geen algemene bepaling (resp. algemene begrip) is nie, en die woord (asook begrip) "geloof" nie gevorm is volgens die skema algemeen-besonder nie, mag ons spreek van die ,geloof" van 'n Christen, van 'n Jood, van 'n Boeddhis, van 'n nie-Christen wysgeer aan die algenoegsame grond van alle dinge, ens. en kan ons tegelyk die radikale uniekheid van die Christelike geloof (resp. „evangeliegeloof") en sy radikale antitese tot alle „onware geloof" (resp. „afvallige geloof”, resp. „ongeloof”) handhaaf.

Deurdat ek met bostaande die angel uit my kritikus se kritiek (nl. sy foutiewe veronderstelling dat ek 'n ,algemene geloof" sou aanvaar, waarvan „evangeliegeloof" 'n verbesondering sou wees) uithaal, verval sy kritiek wat ek in my Samevatting hierbo opgesom het. M.i. is my gebruik van die woord "geloof" nie in stryd met ons woordeboek van die verbondsverkcer nie. 
Geloof in ruimer sin.

Ek kan my kennend en vertrouend oorgee bv. aan wat ek waarneem of aan die bewyskrag van my denkende afleidings. Daar sonder kan ek geen kennis van wat ek bv. waarneem vorm nie. Ook kan ek die woorde van 'n ander mens, glo". In al dergelike gevalle het ,geloof" ook die kenmerke van kenne, vertroue en oorgawe. Dergelike „geloof" is egter toto coelo verskillend van ,geloof in enger sin". Mag ek dit (soos bv. A. Kuyper en H. Bavinck doen) ook ,geloof" noem? Watter ander woorde moet ek gebruik as dit nie mag nie? Mag ek op grond van bepaalde ooreenkomende trekke tussen hulle, die ,geloof in enger sin" en die "geloof in ruimer sin" skakel, solank in gedagte gehou word dat daar geen ,algemene geloof" bestaan en hulle nié verbesonderings van 'n ,algemene geloof" is nie? Dat dit sin het om hulle te skakel, d.w.s. "geloof" te noem, blyk uit die volgende.

\section{Bestryding van die humanisme.}

Die humanis (let wel: gló) in die outarkie van die mens; die rasionalis bv. in die selfgenocgsaamheid van die mens, in die outonomie van sy rede en die selfbeskikking van sy wil, en die irrasionalis of eksistensiewysgeer bv. in sy outoquaerie (sy fundamentele geskiktheid en reg om grenseloos tot in die diepste verborge geheimenisse te vra) en in sy self-bepaalde (homself vormende) waag. Hy wil in die diepste van sy hart 'n god wees (al is hy ook volgens Sartre 'n mislukte god).

Een van die sterkste wapens in my bestryding van die humanisme is die waarheid dat die mens in die mees fundamentele $\sin$ as kennende en handelende wese 'n ,gelowende" wese is, wesensverskillend van God wat weet sonder om te glo, en van die dier wat nie kan glo nie. Selfs die humanis kan nie anders as om met geloof (bv. aan wat hy waarneem, aan sy moontlikhede, aan sy fundamentele insigte, aan 'n hoër wese of 'n algenoegsame grond van alle dinge) te begín nie (hoe verkeerd sy geloof ook al mag wees). Sonder geloof is handele en denke (in die algemeen: menslike ,ervaring") nie moontlik nie. Máár geloof beteken ,oorgawe aan", „onderwerping aan", ,gelei word deur" dit waaraan geglo word; en dit is die teenoorgestelde van outarkie. Hierdie kragtige wapen slaan my kritikus uit my hande as hy eis dat geloof net ,evangeliegeloof" mag beteken.

\section{Die taal van die verbondsverkeer.}

Met hierdie wapen spreek ek nóg nie taal van die verbondsverkeer, handhaaf ek juis die antitese van ware geloof en onware geloof (resp. ongeloof) en spreek ek nóg die taal van 'n gelowige. Dit is die geval omdat die taal (soos reeds aangetoon) nie net uit woorde bestaan nie, maar ook uit sinne; en ook jou sin-gebruik moet in die teken van die verbondsverkeer staan. Ons het dan ook meer as nét die woordeboek van die verbondsverkeer nodig. Dat dr. v. d. W. as predikant en teoloog die besondere en geregverdigde klem lê op die uniekheid van geloof as „evangeliegeloof" en op sy radikale antitese tot ,ongeloof", en van hieruit my wysgerige onderskeidings as bedenklik aanvoel (uitgaande van die foutiewe veronderstelling dat ek 'n ,algemene geloof" sou aanvaar) verstaan ek. Dat ek 'n enigsins ander taal'o) spreek as hy, omdat 
ons Calvinistiese Wysbegeerte "geloof" óók in ander perspektiewe sien, en dat hierdie taal nógtans in verbondsverkeer staan, solank hierdie Wysbegeerte getrou ,in U lig" beoefen word, hoop ek, sal hy my toegee. Dat my kritikus ons (die leser en myself) met sy kritiek opnuut tot self-

1) Sien Koers, XXVIII, 7/8; Jan./Feb. 1961.

2) Met die oog op ons taal-probleem gebruik ek die woord "betekenis" hier opsetlik homoninies. Die verskillende betekenisse wat ek aan "geloof" heg, maak "gcloof" nie homonimies nie.

3) Alhoewel ek nie presies weet wat hy onder bv. "openharing" en ,algemene genade" verslaan nie; hoe hy tussen ,geloof in dic Bybcl" en ,geloof aan die woorde van die Vader ons in die Bybel geopenbaar" onder. skei nie; en ek sou verkies om te spreek van "geloof in God Drie-enig" i.p.v. net in "evangeliegcloof" omdat die mens voor die sondeval ook geloof gehad het.

4) In die O.T. beteken "geloof" dikwels bv. "geloof nan menslike mededelings".

5) Vgl. bl. 328, kol. 1, reel 14. Interessant is die teëspraak waarin hy in hierdie kolom verval. Eers sê hy: „Die Jode... het... naturlik... geglo in 'n algenoegsame Grond van alle dinge, ... al het hulle Christus verwerp". Later sê hy: „Die geloof in die Grond van alle dinge kan nie losgemaak word... van die geloof... in Christus nie."

6) Want dan sou vir die betrokke ánder betekenisse van dieselfde woorde ánder woorde gevorm moet word en die woordeskat van die woordebock van die verbondsverkeer onbruikbaar groot moet word.

7) Hoe soul elk van die volgende woorde (wat ek in die haas versamel het deur „willekeurig in die Verklarende Afrikaanse Woordeboek van Kritzinger, Labuschagne, e.a. te blaai) sy verskillende maar saamhangende betekenisse gekry het, nl. bedoeling, brand, dof, fluit, gang, loop, loot, idee, naald, natuur, ens.? By elk van die woorde is die onderskeie betekenisse geen ondersoek verplig het, en dit oor so 'n ingrypende en indringende problematiek, verdien volle waardering.

\section{H. G. Stoker.}

\section{P.U. vir C.H.O.}

besondere eksemplare van 'n algemene betekenis nie. Dit geld mutatis mutandis ook m.b.t. verskillende gevalle van die vorming van wetenskaplike terminologie.

7a) Op die besondere onderskeid tussen ngods. dienstige gelool" en "religieuse geloof" hoef ek hier nie in te gaan nie.

7b) "Gelool" is m.i. geen (pistentiese) Junksie nie.

8) Alhoewel dr. v. d. W. van ,glo" én van "inhoud van die geloof" spreek, vermy hy die uitdrukkings: „fides qua” (die geloof waarmee jy glo) en "fides quae" (die geloof waaraan jy glo). Ek vermy hulle ook, o.a. omdat die "lides quae" 'n valse probleemstelling inhou. As bv. iemand Sondags saam mel die gemeente bely: „Ek glo in God die Vader, die Skepper van hemel en aarde..." dan glo hy ("fides qua") nie aan sy geloof ("fides quae") nie, maar aan die lewende ware God, wat geen "fides quae" is nie. "Fides quae" is bv. die Gereformeerde belydenisse wat agter in ons Palmboek gedruk staan. Hy glo ook daaraan, maar dit is iets anders as geloof aan die lewende, ware God.

9) Volgens ons woordeboek van die verbonds. verkeer moet ons besonder versigtig wees met die gebruik van die woorde "hočr wese". Gebruik ons hierdie woorde tog, dan moct ons onthou dat dit geen alge. mene bepaling is nie, maar 'n saamvatting van 'n disjunksie op grond van bepaalde ooreenkomende trekke. As algemene bepaling is dit 'n abstrakte denkproduk met slegs nominele (resp. nominalistiese) bete. kenis.

10) In die $\sin \mathrm{nl}$. waarin ook Wiskunde ' $\mathrm{n}$ ander taal spreek as Sielkunde en Chemie 'n ander taal spreek as Sosiologie. 